\title{
Polypyrrole-modified starch films: structural, thermal, morphological and electrical characterization
}

\author{
Caroline T. Vasques, ${ }^{1}$ Susana C. Domenech, ${ }^{2}$ Pedro L. M. Barreto, ${ }^{3}$ Valdir Soldi ${ }^{1 *}$ \\ ${ }^{1 *}$ Grupo de Estudos em Materiais Poliméricos. Universidade Federal de Santa \\ Catarina, Departamento de Química , 88040-900 Florianópolis-SC, Brazil; e-mail: \\ vsoldi@qmc.ufsc.br. \\ ${ }^{2}$ Universidade do Estado de Santa Catarina, Centro de Ciências da Saúde e do \\ Esporte, Laboratório de Instrumentação. 88080-350 - Florianópolis-SC, Brazil. \\ ${ }^{3}$ Departamento de Ciência e Tecnologia dos Alimentos. Universidade Federal de \\ Santa Catarina, 88034-001 - Florianópolis-SC, Brazil.
}

(Received: 25 February, 2008; published: 11 March, 2010)

\begin{abstract}
Starch films were obtained by incorporating sorbitol and $\mathrm{FeCl}_{3} \cdot 6 \mathrm{H}_{2} \mathrm{O}$ by casting. The films were exposed to pyrrole vapors to promote polymerization. $\mathrm{PPy} /$ starch films were characterized by rheology, elemental analysis, electrical $d c$ conductivity measurements, X-Ray diffraction, thermogravimetry, SEM and FTIR. Optimal synthesis conditions were obtained with starch films containing $5 \% \mathrm{w} / \mathrm{w}$ of $\mathrm{FeCl}_{3} .6 \mathrm{H}_{2} \mathrm{O}$ and $10 \mathrm{~h}$ of exposure to pyrrole vapors. The method allowed obtaining smooth, homogeneous films, with electrical conductivity values up to ca. $3.5 \times 10^{-6}$ $\mathrm{S} . \mathrm{cm}^{-1}$. The results suggest that a complex of starch and ferric chloride is formed properties of which are not influenced by the presence of polypyrrole. No chemical interactions were observed between polypyrrole and starch in the film.

Keywords: maize starch; polypyrrole; biomaterials
\end{abstract}

\section{Introduction}

In recent years, artificial materials are of growing importance in medicine and biology. They have been designed to substitute irreversibly damaged tissues and organs. In construction of biocompatible artificial implants, one strategy aims at creation of materials promoting attachment, migration, proliferation, differentiation, long-term viability and cell functioning in a controllable manner, if possible. These materials can be constructed as surfaces colonized by cells, such as heart valves or vascular prostheses lined by contiguous, mature, naturally thromboresistant, nonimmunogenic and semipermeable endothelial layer [1-3], bone implants inducing formation of mineralized osseous tissue only at the interface of native tissue and artificial material [4], or skin substitutes containing polymeric sheet with a feeder layer of fibroblasts covered by keratinocytes [5].

Some biopolymers are already under clinical use, including polyglycolic acid, polylactic acid, and polyhydroxybutyrate, among others [6]. Recently, starch-based polymers and mixtures are a potential alternative [7] and have been investigated in order to replace synthetic polymers. In this field, many efforts have been devoted to the development of improved biomaterials, characterized by highly specialized surfaces, able to interact positively with the biological environment. A great deal of work has pointed out that immobilization of cell adhesive peptides containing RGD (arginine-glycine-aspartic acid) sequence on different polymer surfaces significantly increases cell adhesion on these substrates [8-10]. 
In this work, attention was addressed to the development of a biopolymer material to be used in the orthopaedic field, able to interact with implantation sites in order to stimulate the osteointegration process. Some authors reported that the direct grafting of polypeptides onto surfaces, such as titanium based materials [11], led to poorly stable systems. In order to avoid the problems generated by the use of metallic implants, the strategy followed in this work was based on the surface modification of starch-based films with a conducting polymer, to which biologically active molecules could be grafted by exploiting the polymer surface chemical reactivity. Electrically conducting polymers provide potentially interesting surfaces for cell culture in that their properties (e.g. surface charge and wettability) can be altered reversibly by chemical or electrochemical oxidation or reduction [12] Polypyrrole (PPy) has been chosen which found interesting applications in the biological field, i.e. as active material for endothelial cell culture [12], substrate for immunoreactions [13], electrochemically controlled drug release and substrate for protein [14] and DNA [15] binding. Moreover, its biocompatibility with respect to mammalian bone cells [16] has been already tested. This study describes the preliminary results in the development of a polypyrrole-modified starch film and its characterization by elemental analysis, electrical conductivity measurements, WAXS, SEM, TGA and FTIR analyses. A further step, consisting of grafting of polypeptides containing the adhesive sequence to PPy-modified starch films and cell adhesion experiments is still in progress.

\section{Results and discussion}

\section{Starch Rheology}

The purpose of adding plasticizers is to overcome the starch film brittleness and improve their flexibility and extensibility. Plasticizers must be compatible with filmforming polymers, reduce intermolecular forces and increase the mobility of polar polymer chains. Hydrophilic compounds such as polyols (glycerol, sorbitol and poly(ethylene glycol)) are commonly used as plasticizers in hydrophilic film formation [19]. The plasticizer effectively reduces internal hydrogen bonding while increasing intermolecular spacing [20], thereby decreasing brittleness.

In this work, rheological measurements were primarily conducted to observe if the presence of a plasticizer promotes modifications on the gelatinization conditions of starch. These experiments were carried out in order to confirm whether the method of film preparation is suitable for promoting gelatinization of starch granules in suspension, as a way to obtain the desired film properties. For this purpose, starch granules dispersed in aqueous medium (in absence and in presence of sorbitol) were heated at a constant rate in a rheometer. Figures 1-A and 1-B illustrate the rheological behavior of starch suspensions (in absence and in presence of sorbitol, respectively) during heating under constant shear deformation.

At the beginning of the rheological experiment (Stage a in Figures 1-A and 1-B), the starch suspensions were below $25.0{ }^{\circ} \mathrm{C}$, and viscosity values are similar to those of water (1 mPa.s). Under these conditions, the starch granules were insoluble in water.

A morphological analysis (do not shown) of the starch granules at Stage a, showed a mixture of rounded and angular granules with a centric hilum typically observed in native starch granules [21-22].

As the heating process started, the viscosity of the suspension remained unchanged until a marked increase was observed, when the suspension temperature reached 
$67.0^{\circ} \mathrm{C}$, indicating the gelatinization of the starch suspension (Stage b, in Figure 1A). Under these conditions gelatinization occurs while starch granules swell under water absorption and increase in volume.
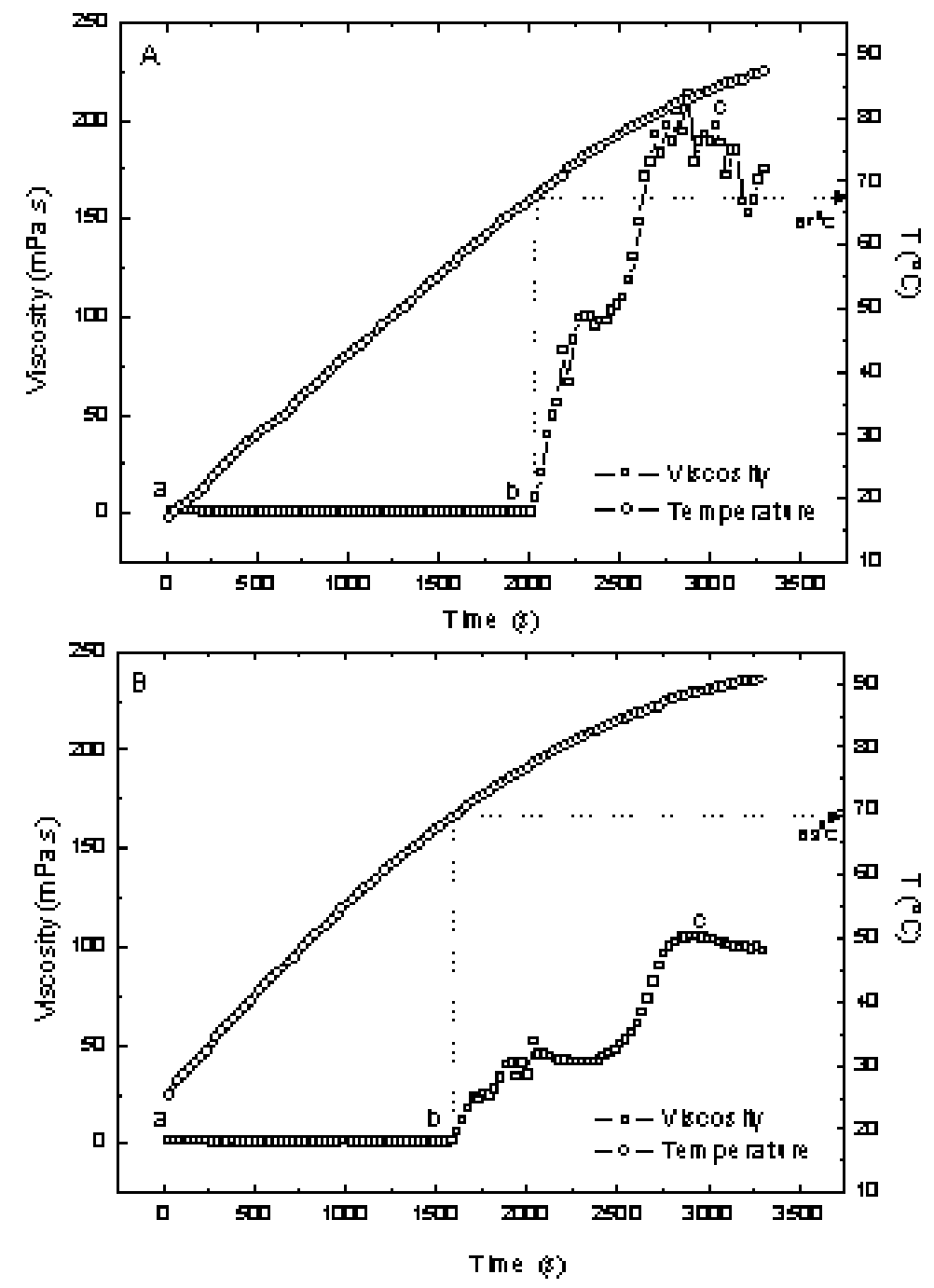

Fig. 1. Viscosity and temperature profiles of an aqueous maize starch suspension (6 $\%, \mathrm{w} / \mathrm{w}): \mathrm{A})$ in absence and $\mathrm{B})$ in presence of sorbitol $(20 \% \mathrm{w} / \mathrm{w})$ obtained during heating in a rheometer at constant shear rate of $93 \mathrm{~s}^{-1}$.

This process was also observed at a temperature of $69.0{ }^{\circ} \mathrm{C}$ for the starch suspension containing sorbitol (Stage $b$, in Figure 1-B). On increasing the temperature, the viscosity values continued to increase as result of swelling up to a maximum of $212.5 \mathrm{mPa}$.s at $82.8^{\circ} \mathrm{C}$ for the starch suspension (Figure $1-\mathrm{A}$ ) and of $105.5 \mathrm{mPa}$.s at $88.3^{\circ} \mathrm{C}$ for the starch suspension containing sorbitol (Figure 1-B). After this point, a decrease in the viscosity was observed due the breakdown of the starch granules, which indicates that this method of preparation allows the complete gelatinization of starch (stage $\mathrm{c}$, in Figures 1-A and 1-B). No marked influence on the gelatinization conditions of the starch granules was observed as a consequence of the presence of sorbitol. 
Polypyrrole synthesis into the starch films

The method described in this work consisting of the incorporation of the oxidizing agent $\left(\mathrm{FeCl}_{3} \cdot 6 \mathrm{H}_{2} \mathrm{O}\right)$ into the starch/sorbitol mixture (after gelatinization) allowed obtaining homogeneous, apparently smooth films, with a thickness of $(0.173 \pm 0.002)$ $\mathrm{mm}$. Films containing different concentrations of $\mathrm{FeCl}_{3} \cdot 6 \mathrm{H}_{2} \mathrm{O}(1-10 \% \mathrm{w} / \mathrm{w})$ were produced in order to determine the optimal synthesis conditions of polypyrrole into the starch/sorbitol matrices. Figures 2-A and 2-B depict the pyrrole sorption and pyrrole polymerization respectively, as function of exposure time to pyrrole vapors.
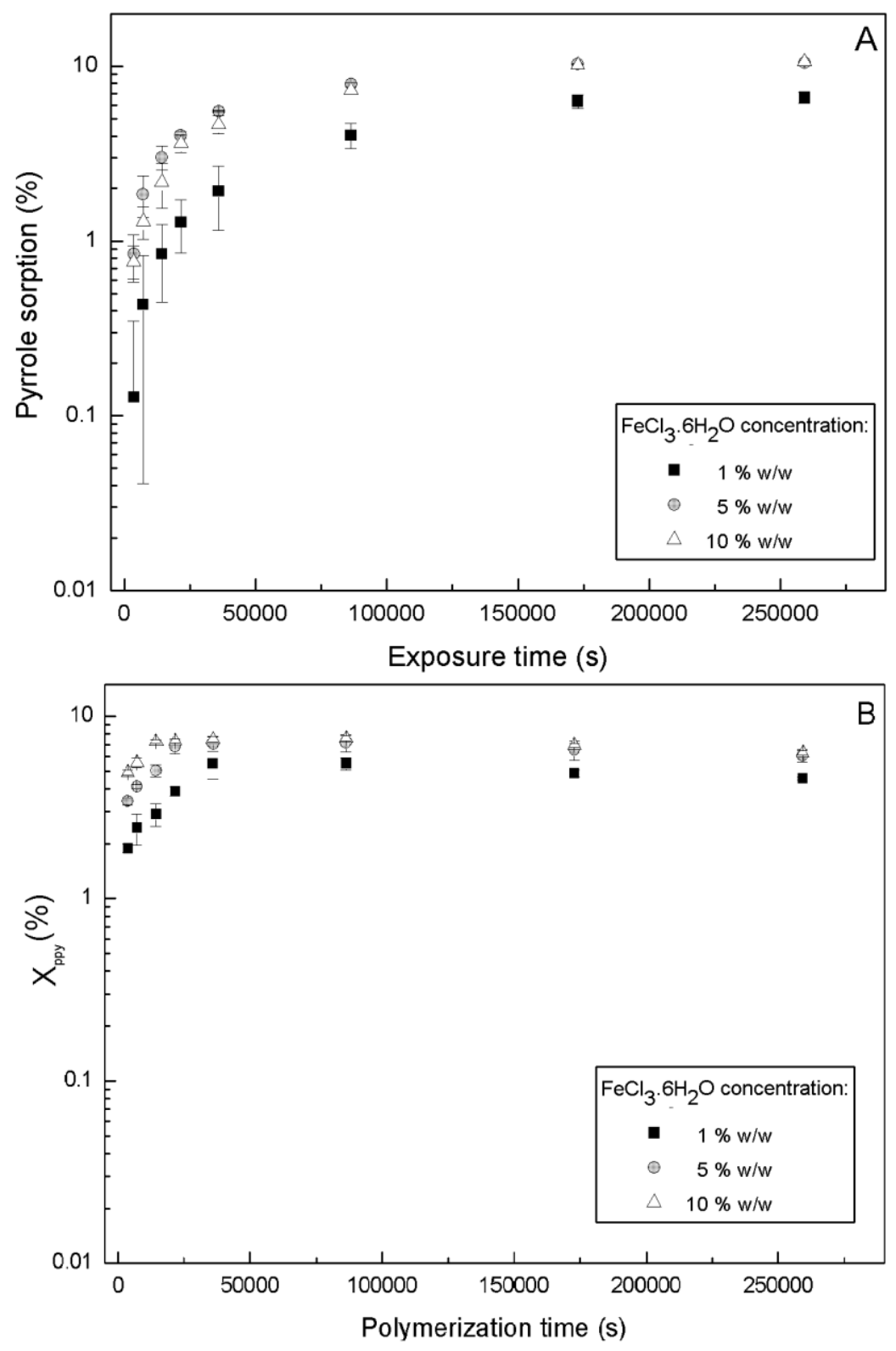

Fig. 2. Plots of: A) Pyrrole sorption and B) pyrrole weight fraction as function of exposure time to pyrrole vapor, of starch films containing $20 \% \mathrm{w} / \mathrm{w}$ of sorbitol and $\mathrm{FeCl}_{3} \cdot 6 \mathrm{H}_{2} \mathrm{O}$ at different concentrations.

In general, all the matrices exposed to pyrrole vapors showed a change of coloration from dark yellow to black, after ca. one hour of monomer exposure, indicating the 
pyrrole polymerization reaction occurring in the starch films. It is interesting to note that the flexibility of the films was maintained after pyrrole polymerization.

It was observed that an equilibrium of pyrrole sorption was of $6.6 \% \mathrm{w} / \mathrm{w} ; 10.5 \% \mathrm{w} / \mathrm{w}$ and $10.6 \% \mathrm{w} / \mathrm{w}$ for films containing $1 \% \mathrm{w} / \mathrm{w} ; 5 \% \mathrm{w} / \mathrm{w}$ and $10 \% \mathrm{w} / \mathrm{w}$ of $\mathrm{FeCl}_{3} .6 \mathrm{H}_{2} \mathrm{O}$ reached after ca. $60 \mathrm{~h}$ of exposure to pyrrole vapors (Figure 2-A). These results are in agreement of those found by Zoppi [23] and Zoppi et al. [24], for PPy/EPDM semiIPN (semi-interpenetrating networks) obtained by mechanical mixing of $\mathrm{FeCl}_{3} \cdot 6 \mathrm{H}_{2} \mathrm{O}$ as oxidizing agent into the rubber matrix, followed by exposure to pyrrole vapors.

On the other hand, the polymerization reaction stabilize after $10 \mathrm{~h}$ of pyrrole vapor exposure for all compositions tested, as can be seen in Figure 2-B. Considering that the monomer is in excess during the polymerization reaction, and that the presence of unreacted $\mathrm{FeCl}_{3} \cdot 6 \mathrm{H}_{2} \mathrm{O}$ could impair the stability of the starch film, the results suggest that $5 \% \mathrm{w} / \mathrm{w}$ of the oxidant are sufficient to promote an adequate pyrrole polymerization into the starch-based film.

To confirm this statement, $\mathrm{PPy}-\mathrm{Cl}$ was chemically prepared with the same mass $(0.05 \mathrm{~g})$ of oxidant previously used to produce the starch film containing $5 \% \mathrm{w} / \mathrm{w}$ of $\mathrm{FeCl}_{3} \cdot 6 \mathrm{H}_{2} \mathrm{O}$. The elemental analysis of the synthesized polymer indicated the presence of $53.64 \% \mathrm{w} / \mathrm{w}$ of $\mathrm{C}, 4.03 \% \mathrm{w} / \mathrm{w}$ of $\mathrm{H}$ and $16.46 \% \mathrm{w} / \mathrm{w}$ of $\mathrm{N}$. The expected content of the elements in PPy-Cl $(62.20 \% \mathrm{w} / \mathrm{w}$ of C, $4.32 \% \mathrm{w} / \mathrm{w}$ of $\mathrm{H}$ and $18.14 \%$ $\mathrm{w} / \mathrm{w}$ of $\mathrm{N}$ ) was calculated assuming that for three pyrrole rings one positive charge is created, which has to be balanced by the anion of the oxidant molecule [25] (Equation 1). These results agree with the findings of Omastová et al [25-27] in studies of the pyrrole chemical polymerization using $\mathrm{FeCl}_{3}$ in $\mathrm{HCl}$ medium, who found a polymerization yield of $1.15 \mathrm{~g} \cdot \mathrm{g}^{-1}$. Omastová et al [25-27] and Machida et al [28] also reported that the optimum $\mathrm{FeCl}_{3} /$ pyrrole molar ratio is 2.3.

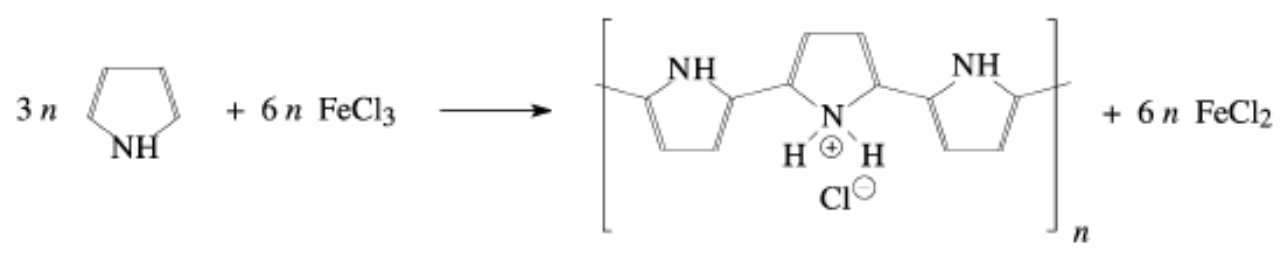

The difference between the experimental and calculated elemental compositions in $\mathrm{PPy}-\mathrm{Cl}$ sample obtained in this work can be partly explained by the fact that polypyrrole is hygroscopic and contains up to $4.4 \% \mathrm{w} / \mathrm{w}$ of water, as was found in the TGA curve (do not shown) [25-27]. PPy contains also oxygen, the presence of C$\mathrm{O}, \mathrm{C}-\mathrm{OH}$ and $\mathrm{C}=\mathrm{O}$ bonds was proved in the PPy samples [29-30]. The oxygen may enter into PPy structure during the polymerization process itself as the consequence of the presence of water in the starch film, as well as by reaction of the prepared polymer with atmospheric oxygen.

\section{Fourier-transform Infrared spectroscopy}

Figure 3 shows the FTIR spectra of a starch film, sorbitol, polypyrrole, and starch films containing $20 \% \mathrm{w} / \mathrm{w}$ of sorbitol and $5 \% \mathrm{w} / \mathrm{w}$ of $\mathrm{FeCl}_{3} \cdot 6 \mathrm{H}_{2} \mathrm{O}$ before and after pyrrole vapor exposure.

The FTIR spectrum a in Figure 3 depicts a typical pattern of starch, which is in agreement with the descriptions in the literature [31]. A broad band was observed at 
$3500-3000 \mathrm{~cm}^{-1}$ [32-33], in which the main absorption band $\left(3288 \mathrm{~cm}^{-1}\right)$ is related to bonded hydroxyl groups of the starch. The absorption bands at ca. $2940 \mathrm{~cm}^{-1}$ and $2885 \mathrm{~cm}^{-1}$ refer to the C-H stretching in the starch [33]. In the region $2000-400 \mathrm{~cm}^{-1}$, the main absorption bands correspond to bound water at ca. $1648 \mathrm{~cm}^{-1}, \mathrm{C}-\mathrm{H}$ bending at ca. $1400-1460 \mathrm{~cm}^{-1}$, and bands associated with $\mathrm{C}-\mathrm{O}, \mathrm{C}-\mathrm{C}$ and $\mathrm{C}-\mathrm{O}-\mathrm{H}$ in the region $1200-900 \mathrm{~cm}^{-1}$ [32]. The band position related to the scissoring mode of residual water is dependent on the polysaccharide crystallinity. For studies on crystalline trehalose (a disaccharide) for example, it has been reported that the band related to water absorption appears at $1685 \mathrm{~cm}^{-1}$, indicating the presence of strong hydrogen bonding and for amorphous trehalose, this band has been observed at $1648 \mathrm{~cm}^{-1}$ [32]. Zhang et al [33] report that peaks at ca. $1649 \mathrm{~cm}^{-1}$ are believed to be a feature of tightly bound water present in the starch. The bands located at ca. $1458 \mathrm{~cm}^{-1}$, $1257 \mathrm{~cm}^{-1}$ and $855 \mathrm{~cm}^{-1}$ are assigned to the vibrations associated with the $\mathrm{CH}_{2}$ group [31]. The frequencies at ca. $1349 \mathrm{~cm}^{-1}$ and $1002 \mathrm{~cm}^{-1}$ were demonstrated to be due to modes involving deformations of $\mathrm{C}-\mathrm{OH}$ groups [32]. In addition, the modes related to $\mathrm{CCH}$ bending were identified at around $1421 \mathrm{~cm}^{-1}, 1208 \mathrm{~cm}^{-1}$ and $1080 \mathrm{~cm}^{-1}$, while the C-O and C-C stretching contribute to modes related to the bands $1154 \mathrm{~cm}^{-1}, 1113$ $\mathrm{cm}^{-1}$ and $933 \mathrm{~cm}^{-1}$ [31]. Finally, the bands associated with the $\mathrm{C}-\mathrm{O}$ and $\mathrm{C}-\mathrm{O}-\mathrm{H}$ has been assigned to glycosidic linkage [34].

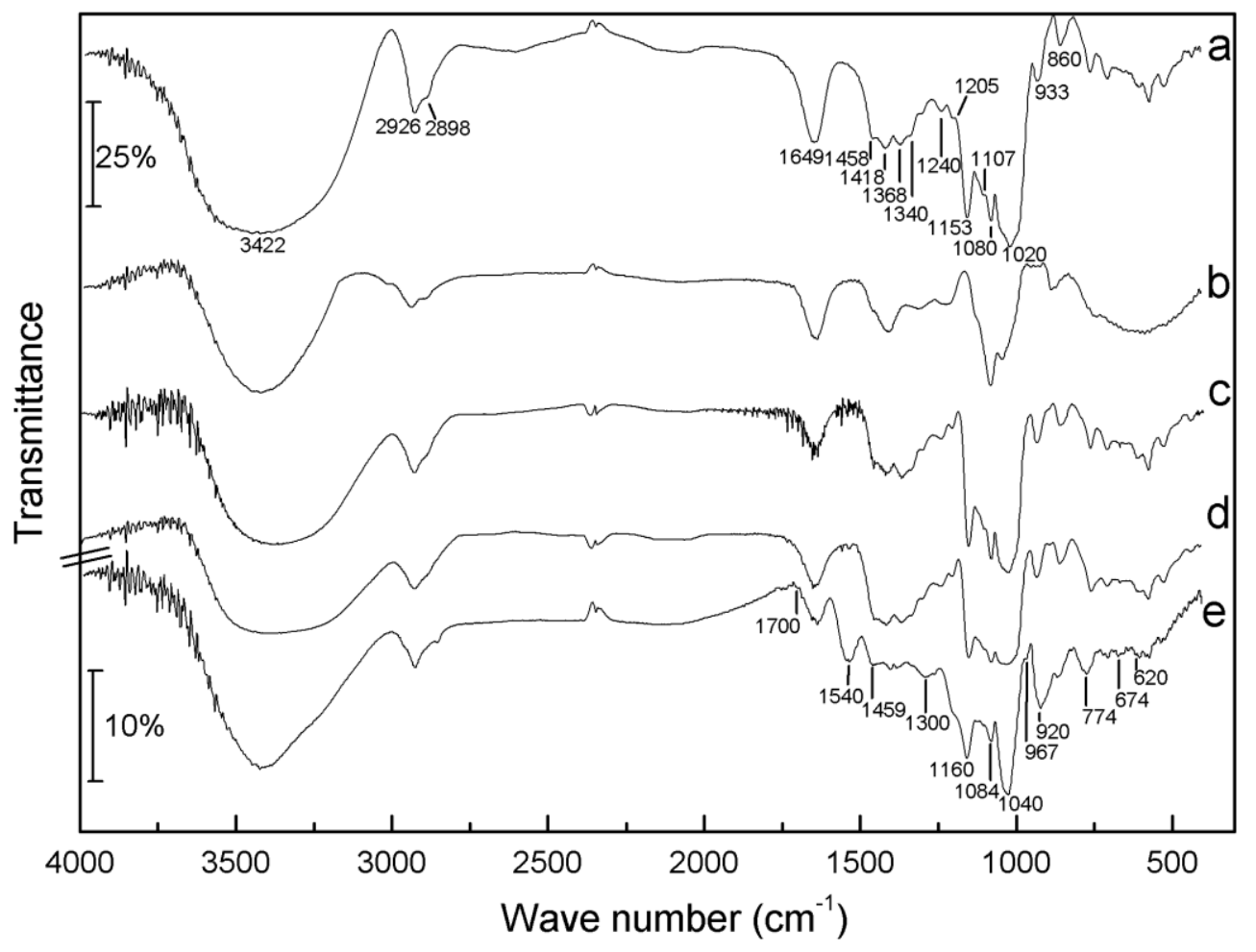

Fig. 3. FTIR spectra of: a) starch film; b) sorbitol; c) starch film containing $20 \% \mathrm{w} / \mathrm{w}$ of sorbitol and $5 \% \mathrm{w} / \mathrm{w}$ of $\mathrm{FeCl}_{3} .6 \mathrm{H}_{2} \mathrm{O}$; d) polypyrrole; e) starch film containing $20 \%$ $\mathrm{w} / \mathrm{w}$ of sorbitol and $5 \% \mathrm{w} / \mathrm{w}$ of $\mathrm{FeCl}_{3} \cdot 6 \mathrm{H}_{2} \mathrm{O}$ after $24 \mathrm{~h}$ of exposure to pyrrole vapors.

The spectra $\mathrm{b}$ and $\mathrm{c}$ of Figure 3 were obtained from sorbitol, and from a starch film containing $20 \% \mathrm{w} / \mathrm{w}$ of sorbitol and $5 \% \mathrm{w} / \mathrm{w}$ of $\mathrm{FeCl}_{3} .6 \mathrm{H}_{2} \mathrm{O}$, respectively. As mentioned before, plasticizers play a very important role in the starch film formation affecting the film structure and, accordingly, its properties [35]. The basic rationale of 
the plasticization is that plasticizers can attract the water molecules, reduce the intermolecular interactions between the biopolymer chains and increase the flexibility of films [36]. Without plasticizers, starch films are readily broken into fragments when they are dried under ambient conditions. The working parts or active sites in plasticizers and starch are their hydrophilic parts, such as hydroxyl groups. Therefore, some polyols (especially, glycerol, sorbitol, and ethylene glycol) are considered as preferred plasticizers for starch-film production [37]. In this work, the use of sorbitol as plasticizer leads to flexible starch films with a smooth appearance (Figure 4-B). Considering these affirmations, no significant shifts on the vibration modes of starch spectrum were observed with the presence of sorbitol. Specifically, the peak at $1648 \mathrm{~cm}^{-1}$ observed in spectra a and b of Figure 3 (related to bound water) is not modified in spectrum c. Therefore, it can be concluded that sorbitol acted as plasticizer by itself efficiently reducing the interaction between the starch polymers.

Zhang and Han [33] in studies of plasticization of pea starch films with several monosaccharides and polyols, also reported that no changes in the FTIR spectrum of pea starch were observed due the presence of sorbitol. These authors suggest that that sorbitol behave like monosaccharides in starch films. In addition, Yang and Paulson [35] report that sorbitol is a hydrogenation product of glucose and its molecules are supposed to be present similar to the ring conformations of the glucose molecules.

Considering the presence of $\mathrm{FeCl}_{3} \cdot 6 \mathrm{H}_{2} \mathrm{O}$ in the starch film, Tomasik et al. [38] affirm that ferric chloride forms with starch an inclusion complex which can be readily hydrolyzed into the starch- $\mathrm{Fe}(\mathrm{O}) \mathrm{OH}$ complex. Contrary to it, if carbonyl iron powder reacts with starch paste at $37^{\circ} \mathrm{C}$, it gives starch ferrate. These compounds present different structure and properties, especially those related to water binding capacity and aqueous solubility. These authors [38] also report that the properties of the starch complex and of the complex resulting from its hydrolysis qualitatively resemble properties of the complexes prepared and described by other authors [39]. In Figure 3 , the strong band observed in the spectrum a (of starch) at around $3300 \mathrm{~cm}^{-1}$ (hydroxyl groups) was shifted to lower wavenumbers in spectrum c (of starch film containing sorbitol and ferric chloride). It suggests that the changes in the effective amount of the hydroxyl groups existing in the films was not due to the presence of sorbitol, but probably due the formation of a complex with $\mathrm{FeCl}_{3} .6 \mathrm{H}_{2} \mathrm{O}$, which a different structure and properties than the original starch film. This affirmation is based on the decrease of the solubility in water of starch films starch observed in those containing the oxidant, and on the above mentioned TGA, X-Ray diffraction and SEM results.

Several research groups [25, 40-44] have made the assignments of vibration modes of PPy. The spectra e of Figure 3 (polypyrrole powder synthesized with $\mathrm{FeCl}_{3}$, so called PPy-Cl) contains bands at $1540 \mathrm{~cm}^{-1}$ (C-C stretching vibrations in pyrrole ring) [25], at $1459 \mathrm{~cm}^{-1}$ (C-N stretching vibration in the ring) [25]; from $1400 \mathrm{~cm}^{-1}$ to 1250 $\mathrm{cm}^{-1}$ (broad band, $\mathrm{C}-\mathrm{H}$ or $\mathrm{C}-\mathrm{N}$ in-plane deformation modes of secondary aromatic amines) [25,42], bands from 1250 to $1100 \mathrm{~cm}^{-1}$ (vibrations of the pyrrole ring) [25], characteristic for oxidized polypyrrole. Vibrations from $1130 \mathrm{~cm}^{-1}$ to $1000 \mathrm{~cm}^{-1}(\mathrm{C}-\mathrm{H}$ and $\mathrm{N}-\mathrm{H}$ in plane deformation vibrations) and the band at $1700 \mathrm{~cm}^{-1}$ are influenced by C-O vibration of hydroxypyrrole units formed by nucleophilic attack of water during the preparation [25]. The band at $1084 \mathrm{~cm}^{-1}$ corresponds to the mode of in-plane deformation vibration of $\mathrm{N}^{+} \mathrm{H}_{2}$ which is formed on the PPy chains by protonation 
(Equation 2) [25]. Finally, bands at $1040 \mathrm{~cm}^{-1}(\mathrm{C}-\mathrm{H}$ and $\mathrm{N}-\mathrm{H}$ in-plane deformation vibration), at $967 \mathrm{~cm}^{-1}$ (C-C out of plane ring deformation), at $774 \mathrm{~cm}^{-1}$ (C-H out of plane ring deformation), at $674 \mathrm{~cm}^{-1}$ (C-C out-of plane ring deformation) and at 620 $\mathrm{cm}^{-1}$ (N-H out of plane vibration) were found for PPy-Cl [25, 44].

Finally, the spectrum $d$ (Figure 3 ) related to a starch film prepared $20 \% \mathrm{w} / \mathrm{w}$ of sorbitol and $5 \% \mathrm{w} / \mathrm{w}$ of $\mathrm{FeCl}_{3} \cdot 6 \mathrm{H}_{2} \mathrm{O}$ after pyrrole vapor exposure was obtained in order to observe possible interactions between polypyrrole and the starch film. This spectrum resembled a superpositioning of the spectra of the different components of the film. Compared with the plain components, nearly the same absorption bands of $\mathrm{PPy}-\mathrm{Cl}$, sorbitol and starch complex were observed. No evidences of chemical interactions between polypyrrole and the starch based matrix were observed by this technique, suggesting only the formation of a physical mixture.

\section{Morphological analysis}

Figure 4 shows micrographs of starch-based films of different composition. The starch film (Figure 4-A) depicts a homogeneous and compact surface with a rough aspect, without porosities or cracks. In the presence of the plasticizer (Figure 4-B), changes on the film morphology were observed mainly as a diminution of the film roughness. As mentioned before, the presence of sorbitol in starch films promotes modifications in the arrangement of the polymer chains, affecting its crystallinity and morphology, among other properties [45]. Films prepared with sorbitol also diminished their brittleness and became more flexible.

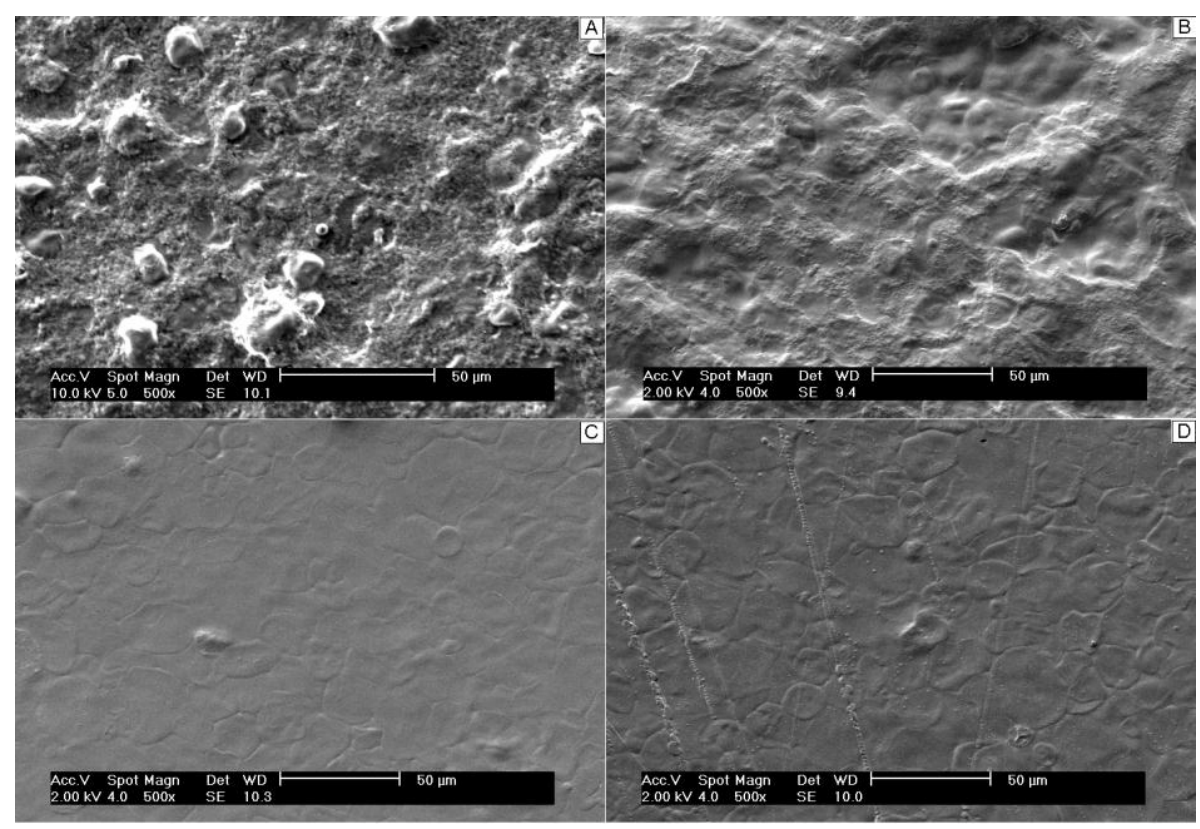

Fig. 4. Scanning electron micrographs of the surface of: a) starch film; b) starch film containing $20 \% \mathrm{w} / \mathrm{w}$ of sorbitol; and starch film containing $20 \% \mathrm{w} / \mathrm{w}$ of sorbitol and 5 $\% \mathrm{w} / \mathrm{w}$ of $\mathrm{FeCl}_{3} \cdot 6 \mathrm{H}_{2} \mathrm{O}: \mathrm{c}$ ) before ; d) after $24 \mathrm{~h}$ of exposure to pyrrole vapors.

However, a more pronounced smooth effect was observed on the surface morphology of starch specimens prepared with sorbitol and $\mathrm{FeCl}_{3} \cdot 6 \mathrm{H}_{2} \mathrm{O}$ (Figure 4-C). These characteristics remained practically unchanged after exposure to pyrrole vapors (Figure 4-D), with exception of a marked color change from yellow to black, after pyrrole exposure, indicating the pyrrole polymerization reaction occurring in the 
starch films. No domains of phase separation can be observed at these micrographs. The changes on the starch diffraction pattern (as will be further described) as well as of the morphology due to the presence of ferric chloride were also accompanied by a decrease in water solubility of the films as observed in laboratory tests (do not shown). This behavior strongly suggests that probably a reaction between starch and the oxidant occurred, with the formation of a complex as reported by Tomasik et al. [38]. Due to the amorphous character of polypyrrole, crystallinity and morphology of the starch- $\mathrm{FeCl}_{3}$ complex were not markedly influenced by the presence of polypyrrole in the film, as will be seen in the following section.

\section{Wide-angle X-ray analysis}

Wide-angle X-ray analysis was conducted with starch powder (native form), polypyrrole powder, a starch film containing $20 \% \mathrm{w} / \mathrm{w}$ of sorbitol and $5 \% \mathrm{w} / \mathrm{w}$ of $\mathrm{FeCl}_{3} .6 \mathrm{H}_{2} \mathrm{O}$ and with a specimen of same composition after surface modification with polypyrrole, in order to observe the main structure of the starting polymers and the films after preparation (Figure 5).

The crystallinity of starch granules is attributed mainly to amylopectin, a highly branched molecule, its side chain branches intertwine to form the double helices, which are the basis of the crystals [46]. Three different types of crystal structures have been identified in the literature, classified by Katz and Van Itallie [47]. These are known as "A-type"- characteristic of cereal starches, "B-type" - found in tuber starches, and "C-type"- found in legumes.

In the native form (Figure 5-a) maize starch presents diffraction peaks corresponding to the Bragg's angle $(2 \theta)$ at ca. $15^{\circ} ; 18^{\circ}$ and $23^{\circ}$, which correspond to a crystalline structure typical of cereal starch "A-type" [46,48-49].

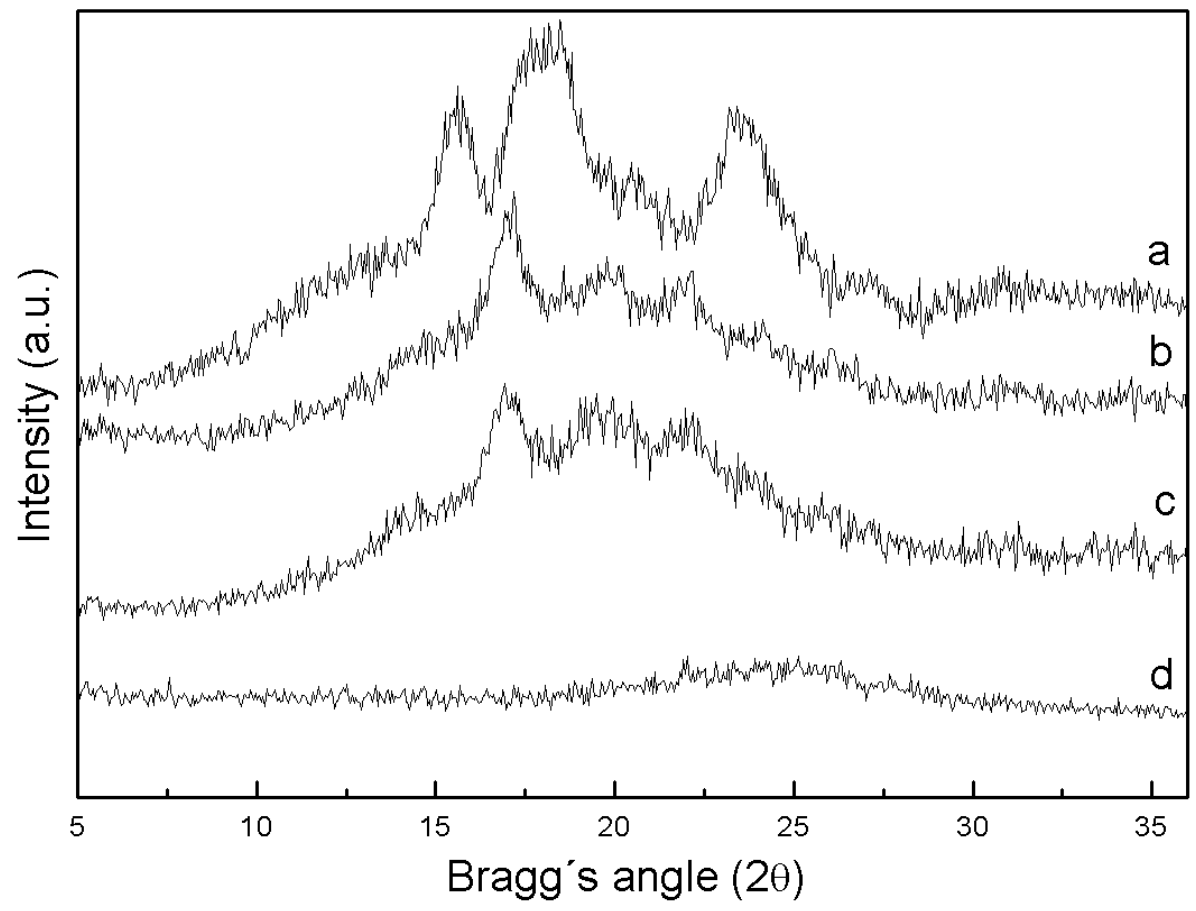

Fig. 5. X-ray diffractograms of: a) starch powder (in nature); starch film containing 20 $\% \mathrm{w} / \mathrm{w}$ of sorbitol and $5 \% \mathrm{w} / \mathrm{w}$ of $\mathrm{FeCl}_{3} \cdot 6 \mathrm{H}_{2} \mathrm{O}: \mathrm{b}$ ) before and c) after $24 \mathrm{~h}$ of exposure to pyrrole vapors; d) polypyrrole powder. 
The gelatinization process promotes the breakdown of the starch granules in suspension. After film casting, a new structure different from the original is formed, which presents diffraction peaks at ca. $17^{\circ} ; 19^{\circ}$ and $22^{\circ}$ as can be seen in the diffractogram of starch film immediately after drying (Fig. 5-b). This different pattern is due the presence of sorbitol and ferric chloride in the starch film. As described by Beerler et al. [45], sorbitol interfere with the arrangement of the polymer chains and with the hydrogen bonding, it also decreases the polymer interaction and cohesiveness and it most likely affect the crystallinity and other physical properties of the films. In addition, it was also reported by Tomasik et al. [38] that ferric chloride forms with starch a complex with structure and properties different than those from the original starch.

The pattern observed in Figure 5-b is not markedly influenced by the presence of polypyrrole, as observed in Figure 5-c. This behavior can be attributed to PPy-Cl which clearly presents an amorphous pattern, as can be seen in Figure 5 -d. The broad reflection in the range of $15-35^{\circ}$ indicates a low order of crystallinity, characteristic for polypyrroles, which agree with the statements of Visy et al. [50] and of He et al. [51], who conducted XRD studies of polypyrrole synthesized with $\mathrm{FeCl}_{3}$.

\section{Thermal analysis}

Figures 6-A and 6-B present the TGA and DTG curves of sorbitol, of starch film and starch films at different compositions, to observe the influence of the different components on the thermal stability of the film.

The thermograms of sorbitol, starch film and starch film containing $20 \% \mathrm{w} / \mathrm{w}$ of sorbitol (curves a, b and $\mathrm{c}$ in Figure 6A, respectively) show a single degradation step with onset at ca. $323{ }^{\circ} \mathrm{C}$ (starch) and ca. $320^{\circ} \mathrm{C}$ (sorbitol) and at ca. $313^{\circ} \mathrm{C}$ (starch film containing $20 \% \mathrm{w} / \mathrm{w}$ of sorbitol). In addition, it is observed that the temperature of maximum degradation rate (peak maximum on the DTG curves in Figure 6B) was $361{ }^{\circ} \mathrm{C} ; 344{ }^{\circ} \mathrm{C}$ and $338{ }^{\circ} \mathrm{C}$ (for sorbitol, starch and starch film containing $20 \% \mathrm{w} / \mathrm{w}$ of sorbitol, respectively) which shows that the starch film containing the plasticizer has lower thermal stability than the starch film. This behavior is probably due sorbitol bind with starch molecules so that the cohesive tension of the molecules in attached polymer chains becomes weakened [52]. In addition, it is homogeneously incorporated within a network of hydrogen bonds between the starch molecules; therefore, the film becomes more flexible, soft and transparent.

The influence of the presence of the oxidizing agent $\left(\mathrm{FeCl}_{3} \cdot 6 \mathrm{H}_{2} \mathrm{O}\right)$ on the thermal stability of the starch film (containing $20 \% \mathrm{w} / \mathrm{w}$ of sorbitol) can be seen in curve $\mathrm{d}$ (Figures 6-A and 6-B). As observed in this curve, the presence of $\mathrm{FeCl}_{3} \cdot 6 \mathrm{H}_{2} \mathrm{O}$ impaired the thermal stability of the starch film, due to its oxidant character. Since the boiling temperature of sorbitol is ca. $290{ }^{\circ} \mathrm{C}$ [53], the mass loss below $100{ }^{\circ} \mathrm{C}$ is mainly ascribed to water loss and from $100{ }^{\circ} \mathrm{C}$ is probably related to the volatilization of bound-water. At the end of this weight loss it was found a residue of $8.3 \% \mathrm{w} / \mathrm{w}$. At temperatures above ca. $165^{\circ} \mathrm{C}$, two main weight losses were observed in this curve. Considering the previous results, the degradation step starting at ca. $165{ }^{\circ} \mathrm{C}$ is probably related with the thermal decomposition of the formed starch-ferric chloride complex and followed by the degradation of sorbitol and starch at higher temperatures. The presence of a residue of $28.3 \%$ at $600{ }^{\circ} \mathrm{C}$, also suggest the formation of crosslinked structures. 
The influence of polypyrrole on the thermal stability of starch film is observed in curve e (Figures $6 \mathrm{~A}$ and $6 \mathrm{~B}$ ). Compared to curve $d$, the first weight loss in curve $e$ is extended to higher temperatures (ca. $195{ }^{\circ} \mathrm{C}$ ). Up to ca. $100{ }^{\circ} \mathrm{C}$, this loss can be related to water loss, as was also described by Omastová et al. [25], in TGA studies of polypyrroles prepared in the presence of $\mathrm{FeCl}_{3}$. These authors found a significant weight loss occurring at temperatures between $30^{\circ} \mathrm{C}$ and $100{ }^{\circ} \mathrm{C}$ related to evaporation of residual water, due to the hygroscopic character of PPy. Above ca. $100^{\circ} \mathrm{C}$, the weight loss in curve e (Figure $6 \mathrm{~A}$ ) is can be related to the degradation of the PPy chain and/or the starch-ferric chloride complex.
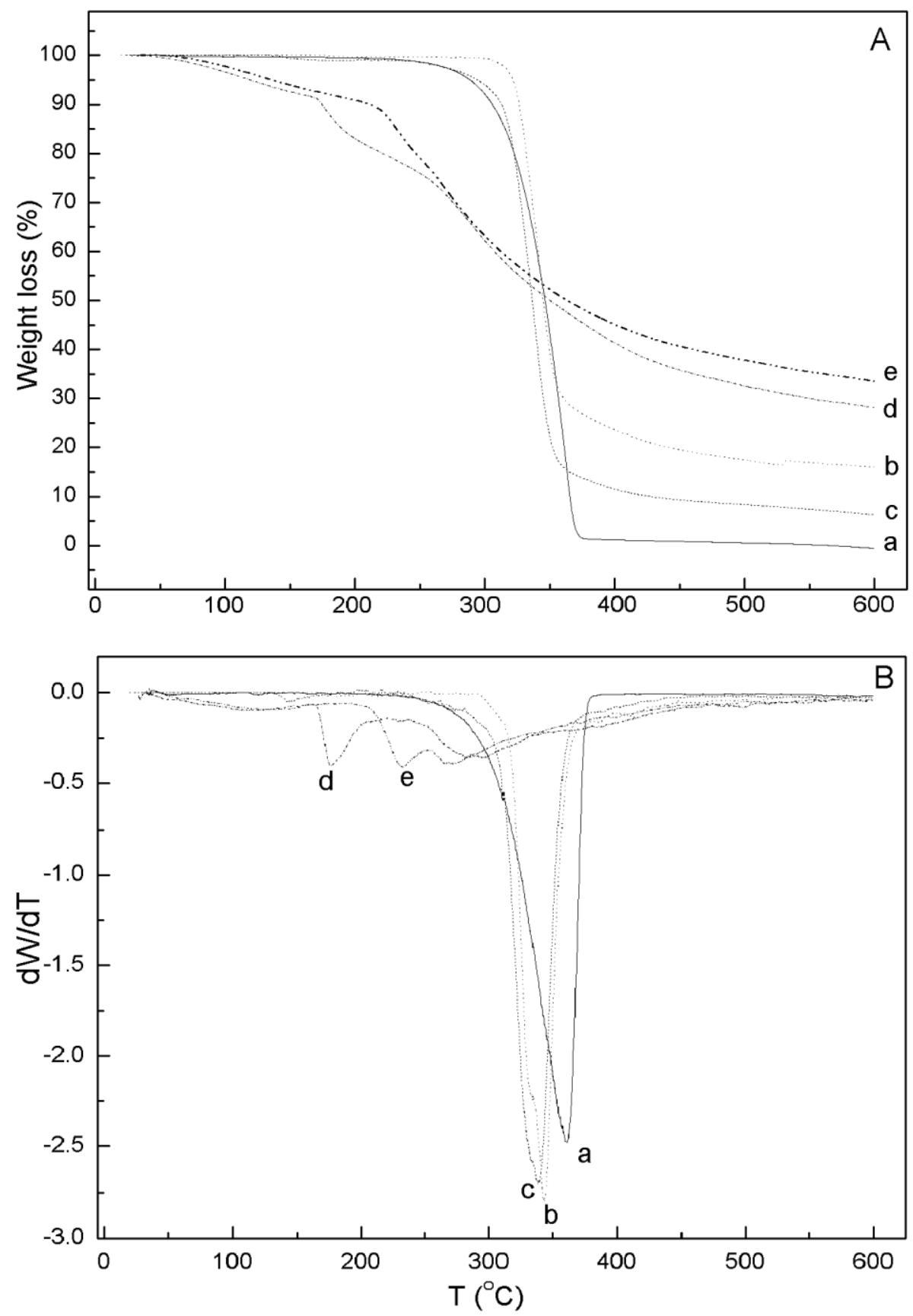

Fig. 6. A) TGA curves and B) DTG curves of: a) sorbitol; b) starch film; c) starch film containing $20 \% \mathrm{w} / \mathrm{w}$ of sorbitol; and starch film containing $20 \% \mathrm{w} / \mathrm{w}$ of sorbitol and 5 $\% \mathrm{w} / \mathrm{w}$ of $\mathrm{FeCl}_{3} \cdot 6 \mathrm{H}_{2} \mathrm{O}:$ d) before; e) after $24 \mathrm{~h}$ of exposure to pyrrole vapors. 
The last weight loss, starting at about $250{ }^{\circ} \mathrm{C}$ probably corresponds to the degradation of sorbitol and starch [53]. In this case, it is also supposed that crosslinking formation takes place at high temperatures, as evidenced by a residue of $33.56 \%$ at the end of the experiment. Compared to curve $d$, it can be observed that the presence of PPy partially avoid the oxidation of starch promoted by $\mathrm{FeCl}_{3} .6 \mathrm{H}_{2} \mathrm{O}$, enhancing the thermal stability of the film, which is maintained up to $195^{\circ} \mathrm{C}$.

\section{Electrical dc conductivity}

In addition, the conductivity of chemically prepared PPy depends on the preparation conditions, temperature and strongly on the used oxidant [54-55]. Then, the choice of the oxidant agent employed in this work was based on the reports in the literature. Ferric chloride is often used for pyrrole chemical oxidation and the conductivity of the final product is higher compared to those produced with other oxidants. As described by Mayers [56] PPy-Cl can reach conductivity values in the range $(1-40) \mathrm{S} . \mathrm{cm}^{-1}$. Omastová et al [25-26] found electrical conductivities of $1.5 \pm 0.4{\mathrm{~S} . \mathrm{cm}^{-1}}^{-1}$ for PPy-Cl chemically prepared using $\mathrm{FeCl}_{3}$ as oxidant in $\mathrm{HCl}$ medium.

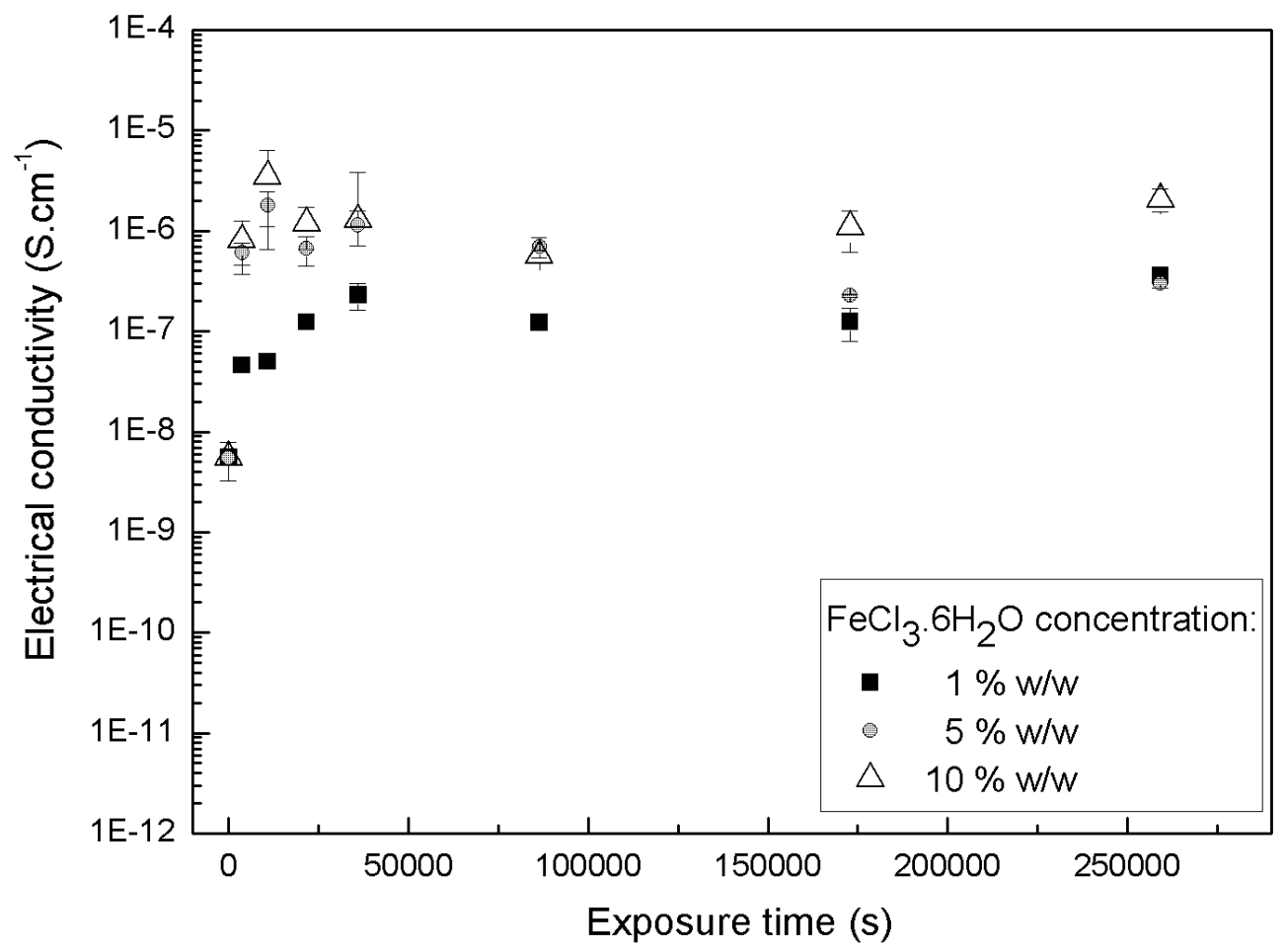

Fig. 7. Electrical $d c$ conductivity as function of exposure time to pyrrole vapor of starch films containing $20 \% \mathrm{w} / \mathrm{w}$ of sorbitol and $\mathrm{FeCl}_{3} \cdot 6 \mathrm{H}_{2} \mathrm{O}$ at different concentrations.

Figure 7 shows the electrical dc conductivity measured on starch films prepared with different contents of $\mathrm{FeCl}_{3} \cdot 6 \mathrm{H}_{2} \mathrm{O}$ as function of exposure time to pyrrole vapors. In a general manner, it was observed that the electrical conductivity tend to increase with exposure time to pyrrole vapors, and remain nearly constant after $10 \mathrm{~h}$ of exposure, 
which is in accordance with the time to polymerization stabilization, previously defined. Compared to the electrical conductivity of the starch films before pyrrole polymerization, the conductivity values of starch films increased from an initial value of $5.53 \times 10^{-9} \mathrm{~S} . \mathrm{cm}^{-1}$ up to a maximum of $3.5 \times 10^{-6} \mathrm{~S} . \mathrm{cm}^{-1}$, depending on time of pyrrole vapor exposure and oxidant concentration in the films. It represents an increase of ca. three orders of magnitude on the electrical conductivity of the starch films, due to the presence of polypyrrole.

Considering the oxidant concentration in the starch films, the conductivity values measured on films at $10 \mathrm{~h}$ of monomer exposure were of $1.28 \times 10^{-6} \mathrm{~S}^{-\mathrm{cm}^{-1}} ; 1.14 \mathrm{x}$ $10^{-6} \mathrm{~S} . \mathrm{cm}^{-1}$ and $2.28 \times 10^{-7} \mathrm{~S} . \mathrm{cm}^{-1}$ for polypyrrole synthesized with $10 \% \mathrm{w} / \mathrm{w}, 5 \%$ $\mathrm{w} / \mathrm{w}$ and $1 \% \mathrm{w} / \mathrm{w}$ of $\mathrm{FeCl}_{3} \cdot 6 \mathrm{H}_{2} \mathrm{O}$, respectively. An explanation to the lower conductivity values found at starch films containing $1 \% \mathrm{w} / \mathrm{w}$ of $\mathrm{FeCl}_{3} \cdot 6 \mathrm{H}_{2} \mathrm{O}$, is due the formation of low molecular weight polypyrroles obtained for this oxidant concentration, and the inhomogeneity of conducting part created using small amount of oxidant. This would also contribute to a lower conductivity compared with polypyrrole with higher molecular weights, as the shortest polymer has a reduced conjugation system for charge carrier mobility [57]. The small difference in the conductivity values of films prepared with $5 \% \mathrm{w} / \mathrm{w}$ and $10 \% \mathrm{w} / \mathrm{w}$ of $\mathrm{FeCl}_{3} .6 \mathrm{H}_{2} \mathrm{O}$, suggest that a concentration of $\mathrm{FeCl}_{3} \cdot 6 \mathrm{H}_{2} \mathrm{O}(5 \% \mathrm{w} / \mathrm{w})$ and $10 \mathrm{~h}$ of vapor exposure are sufficient to synthesize polypyrrole into the starch films and enhance electrical conductivity. Therefore, just to ensure complete polymerization reaction, PPy/starch films were prepared with $20 \% \mathrm{w} / \mathrm{w}$ of sorbitol, $5 \% \mathrm{w} / \mathrm{w}$ of oxidant and after, were exposed for $24 \mathrm{~h}$ to pyrrole vapors prior to characterization.

\section{Conclusions}

The method of preparation of films by the incorporation of the oxidizing agent $\left(\mathrm{FeCl}_{3} .6 \mathrm{H}_{2} \mathrm{O}\right)$ into a starch/sorbitol mixture and followed by pyrrole polymerization by exposure to the monomer vapors allowed obtaining homogeneous, smooth, flexible films, $(0.173 \pm 0.002) \mathrm{mm}$ thick, with conductivity values varying from $5.53 \times 10^{-9} \mathrm{~S} . \mathrm{cm}^{-}$ ${ }^{1}$ to $3.5 \times 10^{-6}{\mathrm{~S} . \mathrm{cm}^{-1}}^{-1}$, depending on the composition. The results of X-ray diffraction analysis, TGA, SEM and FTIR, addition of ferric chloride to the starch dispersion seem to form a complex, with structure and properties different than those from the original starch. The structure of this complex is not influenced by the presence of polypyrrole in the film. The results obtained indicate that no chemical interactions between polypyrrole and the starch based matrix are formed, suggesting only the formation of a physical mixture. Work is in progress on grafting a polypeptide containing the RGD adhesive sequence, tests of citotoxicity, degradation and bioactivity of these modified substrates by cell proliferation experiments.

\section{Experimental part}

\section{Starch films preparation}

Starch-based films were prepared by casting as follows: $1.0000 \mathrm{~g}$ of maize starch $\left(\mathrm{C}_{6} \mathrm{H}_{10} \mathrm{O}_{5}\right)_{n}$ (Sigma-Aldrich) containing ca. $73 \% \mathrm{w} / \mathrm{w}$ amylopectin and ca. $27 \% \mathrm{w} / \mathrm{w}$ amylose was dispersed in $0.05 \mathrm{~L}$ of deionized water and sorbitol (hexane-1,2,3,4,5,6hexaol) (Nuclear) was added as plasticizer. The suspension was heated up (in a closed flask) to reach $70{ }^{\circ} \mathrm{C}$ during stirring (using a magnetic stirrer Microquímica model MQAMA 301) at $200 \mathrm{~s}^{-1}$ for $600 \mathrm{~s}$. Stirring was then maintained at $(70 \pm 5){ }^{\circ} \mathrm{C}$ for $1200 \mathrm{~s}$. The suspension was then stirred without heating up to reach the room 
temperature $\left(25^{\circ} \mathrm{C}\right)$. Furthermore, $\mathrm{FeCl}_{3} \cdot 6 \mathrm{H}_{2} \mathrm{O}$ (purchased from Nuclear) previously dissolved in deionized water was added to the mixture and stirred at $200 \mathrm{~s}^{-1}$ and 25 ${ }^{\circ} \mathrm{C}$ for $7200 \mathrm{~s}$. The final product was poured on an acrylic Petry dish (of $83 \mathrm{~mm}$ of diameter) and dried in an air-circulating chamber at $25{ }^{\circ} \mathrm{C}$ for $48 \mathrm{~h}$. Specimens containing $20 \% \mathrm{w} / \mathrm{w}$ of sorbitol and $1 \% \mathrm{w} / \mathrm{w}$ to $10 \% \mathrm{w} / \mathrm{w}$ of $\mathrm{FeCl}_{3} \cdot 6 \mathrm{H}_{2} \mathrm{O}$ (both concentrations related to the starch content) were prepared by this route.

The gelatinization conditions of starch were stablished in a Brookfield RVDV-III Ultra Rheometer (Middleboro, MA - USA) with a cone/dish head, coupled to a Tecnal TE184 Thermostatized bath (Piracicaba, SP - Brazil) to temperature control. For this experiment, an aqueous dispersion containing $6 \% \mathrm{w} / \mathrm{w}$ of starch and $20 \% \mathrm{w} / \mathrm{w}$ of sorbitol was heated from $25.4{ }^{\circ} \mathrm{C}$ up to $90.6{ }^{\circ} \mathrm{C}$ at a heating rate of $0.025{ }^{\circ} \mathrm{C} . \mathrm{s}^{-1}$, under shear rate of $93 \mathrm{~s}^{-1}$.

\section{Surface modification of starch-based film with polypyrrole}

The starch films containing sorbitol (as plastisizer) and $\mathrm{FeCl}_{3} \cdot 6 \mathrm{H}_{2} \mathrm{O}$ (as oxidizing agent) were exposed to pyrrole $\left(\mathrm{C}_{4} \mathrm{H}_{5} \mathrm{~N}\right)$ (purchased from Acros Organics, used without previous purification) vapors in a dessicator (protected from light) at $25^{\circ} \mathrm{C}$. Monomer sorption in the films was monitored gravimetrically up to $72 \mathrm{~h}$. The monomer (pyrrole) sorption and the polypyrrole weight fraction ( $\mathrm{XPPy}_{\mathrm{PP}} \%$ ) were monitored gravimetrically (Bioprecisa Model FA2104N) at different time periods. To observe the pyrrole sorption, samples were weighed immediately after pyrrole vapor exposure, and to monitor the polypyrrole weight fraction specimens were weighed after drying in vacuo for $7200 \mathrm{~s}$.

For elemental analysis, FTIR and X-Ray analysis, polypyrrole was chemically synthesized as follows: $\mathrm{FeCl}_{3} \cdot 6 \mathrm{H}_{2} \mathrm{O}(10 \% \mathrm{w} / \mathrm{w})$ was dissolved in deionized water and stirred at $200 \mathrm{~s}^{-1}$ and $25{ }^{\circ} \mathrm{C}$ for $7200 \mathrm{~s}$. The solution was poured on an acrylic Petry dish (of $83 \mathrm{~mm}$ of diameter) and dried in a non-deaerated atmosphere at $25^{\circ} \mathrm{C}$ for 24 h. Afterwards, the sample was exposed to pyrrole vapors for $24 \mathrm{~h}$. The obtained polypyrrole powder was washed with deionized water in excess to eliminate $\mathrm{FeCl}_{3} .6 \mathrm{H}_{2} \mathrm{O}$ residues. Potassium thiocyanate (Vetec) was dropped into the wash residue in order to guarantee that all unreacted oxidant was eliminated from the polymer. Finally, PPy was dried in dynamic vacuo at $25^{\circ} \mathrm{C}$ for $7200 \mathrm{~s}$.

\section{Characterization}

PPy composition was determined by elemental analysis using an elemental analyzer (Perkin Elmer, Model $2400 \mathrm{CHN}$, Waltham, MA, USA). The analyses were conducted at a combustion temperature of $925{ }^{\circ} \mathrm{C}$ in the presence of $\mathrm{O}_{2}$.

Electrical $d c$ conductivity measurements were conducted at with the standard fourpoint probe technique [17-18]. Samples were stored at $(23 \pm 1)^{\circ} \mathrm{C}$ and $(50 \pm 5) \%$ of relative humidity for $48 \mathrm{~h}$ previously and the measurements were conducted at the same environmental conditions. Current was applied with a current source (Model 6220, Keithley, Cleveland, USA), and the voltage was measured with an electrometer (Model 6517A, Keithley, Cleveland, USA). Specific dc electrical conductivity was calculated by:

$$
\sigma=\frac{I \ln 2}{V \pi e}
$$


where: $\sigma$ is the specific $d c$ electrical conductivity; $e$ is the specimen thickness $(\mathrm{cm}) ; I$ correspond to the applied current $(A)$ and $V$ is the measured voltage $(V)$.

X-ray diffraction patterns were obtained for starch and polypyrrole powders, as well as for starch films using a X-PERT Philips Diffractometer, using a graphite monocromator with $\mathrm{Cu}-\mathrm{K}_{\alpha}(\lambda=1.5406 \AA)$ radiation, submitted to $40 \mathrm{kV} / 0.030 \mathrm{~A}$, at reflection mode, step of $0.05^{\circ}$, step time of $1 \mathrm{~s}$ at a $\theta / 2 \theta$ Geometry. Starch and starchmodified films $(0.173 \pm 0.002) \mathrm{mm}$ thick were analyzed.

The surface and cross section morphology of the polymer films was observed using a Scanning Electron Microscope (Philips XL 30). To analyze the cross section, starch films of $0.144 \mathrm{~mm}$ were fractured in liquid $\mathrm{N}_{2}$. All samples were sputter coated with a $20 \mathrm{~nm}$ gold layer.

Thermal analysis was conducted using a TGA-50 Shimadzu equipment under $\mathrm{N}_{2}$ $\left(0.83 \mathrm{ml} . \mathrm{s}^{-1}\right)$ and a platinum crucible. Thermogravimetric parameters were determined using the associated TGA-50 software. Non-isothermal experiments were performed with samples of ca. $0.005 \mathrm{~g}$ (previously dryied $25^{\circ} \mathrm{C}$ in vacuo for $7200 \mathrm{~s}$ ) in the temperature range of $25^{\circ} \mathrm{C}$ to $600^{\circ} \mathrm{C}$ at a heating rate of $0.17^{\circ} \mathrm{C} . \mathrm{s}^{-1}$.

The FTIR spectra were obtained in transmission mode using a Bomem (model FTLA, Zurich, Switzerland) instrument, with a resolution of $4 \mathrm{~cm}^{-1}$ in the range of $4000 \mathrm{~cm}^{-1}$ to $400 \mathrm{~cm}^{-1}$. FTIR analysis of sorbitol, $\mathrm{FeCl}_{3} \cdot 6 \mathrm{H}_{2} \mathrm{O}$, native starch powder and polypyrrole powder were carried out using a $\mathrm{KBr}$ support. Starch and starch-modified films $(0.010 \pm 0.001) \mathrm{mm}$ thick were produced for FTIR analysis.

\section{Acknowledgements}

The financial support of CNPq for the PhD fellowship is gratefully acknowledged.

\section{References}

[1] Bordenave, L.; Remy-Zolghadri, M.; Fernandez, P.; Bareille, R.; Midy, D. Endothelium 1999, 6, 267.

[2] Kim, B.S.; Nikolovski, J.; Bonadio, J.; Smiley, E.; Mooney, D.J. Exp. Cell Res. 1999, 251, 318.

[3] Bačáková, L.; Mareš, V.; Lisá, V.; Švorčík, V. Biomaterials 2000, 21, 1173.

[4] Bačáková, L.; Starý, V.; Kofroňová, O.; Lisá, V. J. Biomed. Mater. Res. 2001, 54, 567.

[5] Dvořáková, B.; Holíková, Z.; Vacík, J.; Königová, R.; Kapounková, Z.; Michálek, J.; Prádný, M.; Smetana, K.J.R. Int. J. Dermatol. 2003, 42, 219.

[6] Vaz, C.M.; Reis, R.L.; Cunha, A.M. Biomaterials 2002, 23, 629.

[7] Delvile, J.; Joly, C.; Dole, P.; Bliard, C. Carbohyd. Polym. 2002, 49, 71.

[8] Pierschbacher, M.D.; Ruoslahti, E. Nature 1984, 309, 30.

[9] Ruoslahti, E.; Pierschbacher, M.D. Science 1987, 238, 491.

[10] Lin, H.; Sun, W.; Mosher, D.F.; Garcia-Echeverria, C.; Schaufelberger, K.; Lelkes, P.I.; Cooper, S.L. J. Biomed. Mater. Res. 1994, 28, 329.

[11] DeGiglio, E.; Sabbatini, L.; Zambonin, P.G. J. Biomat. Sci. Polym. Ed. 1999, 10, 845.

[12] Wong, J.Y.; Lager, R.; Ingber, D.E. In: Proceedings of the Natural Academy of Sciences, Washington, 1994, 91, 3201.

[13] Pope, M.R. ; Armes, S.P. ; Tarcha, P.J. Bioconj. Chem. 1996, 7, 436. 
[14] Prezyna, L.A.; Qiu, Y.J.; Reynolds, J.R.; Wneck, G.E. Macromolecules 1991, 24, 5283.

[15] Minehan, D.S.; Marx, K.A.; Tripathy, S.K. Polym. Mat. Sci. Eng. 1991, 64, 341.

[16] De Giglio, E.; Sabbatini, L.; Colucci, S.; Zambonin, G. J. Biomat. Sci. Polym. Ed. 2000, 11, 1073.

[17] Smits, F.M. The Bell Syst. Tech. J. 1958, 20, 711.

[18] Zucolotto, V. Master of Science Dissertation. Processamento por fusão de compósitos poliméricos condutores elétricos. Federal University of São Carlos, São Carlos, Brazil, 1999.

[19] Laohakunjit, N.; Noomhorm, A. Starch/Stärke 2004, 56, 348.

[20] Lieberman, E.R.; Guilbert, S.G. J. Polym. Sci. 1973, 41, 33.

[21] Whistler, R.L.; Bemiller, J.N.; Paschall, E.F. Starch: chemistry and technology. 2nd ed. Academic Press. New York, 1984.

[22] Radley, J.A. Examination and analysis of starch and starch products. 1st ed. Applied Science Publishers, London, 1988.

[23] Zoppi, R.A. PhD Thesis. Materiais Condutores constituídos de Polipirrol e Borracha de EPDM. Universidade Estadual de Campinas, Campinas, 1994.

[24] Zoppi, R.A. Polymer 1996, 37, 1999.

[25] Omastová, M.; Trchová, M.; Kovárŏvá. J.; Stejskalc, J. Synth. Met. 2003, 138, 447.

[26] Omastová, M.; Trchová, M.; Pionteck, J.; Prokeš, J.; Stejskal, J. Synth. Met. 2004, 143, 153.

[27] Omastová, M.; Pionteck, J.; Trchová, M. Synth. Met. 2003, 135-136, 437.

[28] Machida, S.; Miyata, S.; Techagumpuch, A. Synth. Met. 1989, 31, 311.

[29] Tian, B.; Zerbi, G. J. Chem. Phys. 1990, 92, 3886.

[30] Ribo, J.M.; Dicko, A.; Valles, M.A.; Ferrer, N.; Bonett, R.; Bloor, D. Synth. Met. 1989, 33, 403.

[31] Pavlovic, S.; Brandão, P. R. G. Minerals Engineering . 2003, 16, 1117.

[32] Wolkers, W.F.; Oliver, A.E.; Tablin, F.; Crowe, J.H. Carbohyd. Res. 2004, 339, 1077.

[33] Zhang, Y.; Han, J.H. J. Food Sci. 2006, 71, 253.

[34] Kacurakova, M.; Mathlouthi, M. Carbohyd. Res. 1996, 284, 145.

[35] Yang, L.; Paulson, A.T.Food Res. Int. 2000, 33, 563.

[36] Ke, T.; Sun, X.; Trans ASAE 2001, 44, 945.

[37] Mali, S.; Grossmann, M.V.E.; Garcia, M.A.; Martino, M.N.; Zaritzky, N.Z. Carbohydr. Polym. 2002, 50, 379.

[38] Tomasik, P.; Jane, J-J.; Spence, K.; Andernegg, J.W. Starch/Stärke 1995, 47, 68.

[39] Leszczynski, W. Acta Alim. Pol. 1985, 11, 21.

[40] Omastova, M.; Lazar, M.; Kosina, S. Polym. Int. 1994, 34, 151.

[41] Furukawa, Y.; Tazawa, S.; Fujii, Y.; Harada, I. Synth. Met. 1988, 24, 329.

[42] Wang, J.; Neoh, K.G.; Kang, E. T. Thin Solid Films 2004, 446, 205.

[43] Prissanaroon, W.; Ruangchuay, L.; Sirivat, A.; Schwank, J. Synth. Met. 2000, $114,65$.

[44] Mohammadi, A.; Hasan, M.A.; Liedberg, B.; Lundstrőm, I.; Salaneck, W.R. Synth. Met. 1986, 14, 189.

[45] Beerler, A.D.; Finney, D.C. Plasticizers, in modern plastics encyclopedia. 1st ed. Mc Graw-Hill, CA, 1983.

[46] Eliasson, A.-C. Starch in Food: Structure, function and Applications. 1st ed. Woodhead Publishing Cambridge, UK, 2004. 
[47] Katz, J.R.; Van, T.B.I. Z. Phys. Chem. 1930, 150, 90.

[48] Galliard, T. Starches: Properties and Potential. 1st ed. John Wiley, New York, 1987.

[49] Guinesi, L.S.; Róz, A.L.; Corradini, E.; Mattoso, L.H.C.; Teixeira, E.M.; Curvelo, A.A.S. Thermoch. Acta 2006, 447, 190.

[50] Visy, C.; Pintér, E.; Flüei, T.; Patakfalvi, R. Synth. Met. 2005, 152, 13.

[51] He, C.; Yang, C.; Li. Y. Synth. Met. 2003, 139, 539.

[52] Mellan, I. The Behavior of Plasticizer. 1st ed. Pergamon Press, 1961.

[53] Yang, J.; Yu, J. ; Ma, X. Carbohyd. Polym. 2006, 66, 110.

[54] Toshima, N.; Hara, S. Prog. Polym. Sci. 1995, 20, 155.

[55] Planche, M.F.; Thieblemont, J.C.; Mazars, N.; Bidan, G. J. Appl. Polym. Sci. $1994,52,1867$.

[56] Mayers, R.E. J. Electron. Mater 1986, 15, 61.

[57] Khor, E.; Whey, J.L.H. Carbohyd. Polym. 1995, 26, 183. 